University of Nebraska - Lincoln

DigitalCommons@University of Nebraska - Lincoln

Publications from USDA-ARS / UNL Faculty

U.S. Department of Agriculture: Agricultural

Research Service, Lincoln, Nebraska

2021

Forages for Conservation and Improved Soil Quality

John F. Obrycki

USDA-National Laboratory for Agriculture and the Environment

Douglas L. Karlen

USDA-National Laboratory for Agriculture and the Environment

Follow this and additional works at: https://digitalcommons.unl.edu/usdaarsfacpub

Part of the Agriculture Commons

Obrycki, John F. and Karlen, Douglas L., "Forages for Conservation and Improved Soil Quality" (2021). Publications from USDA-ARS / UNL Faculty. 2518.

https://digitalcommons.unl.edu/usdaarsfacpub/2518

This Article is brought to you for free and open access by the U.S. Department of Agriculture: Agricultural Research Service, Lincoln, Nebraska at DigitalCommons@University of Nebraska - Lincoln. It has been accepted for inclusion in Publications from USDA-ARS / UNL Faculty by an authorized administrator of DigitalCommons@University of Nebraska - Lincoln. 


\title{
Chapter
}

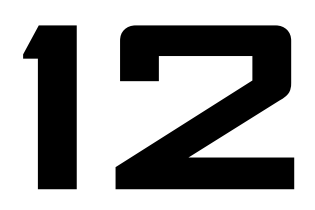

\section{Forages for Conservation and Improved Soil Quality}

\author{
John F. Obrycki, ORISE Fellow, USDA-National Laboratory for Agriculture and the \\ Environment, Ames, IA, USA \\ Douglas L. Karlen, Soil Scientist (Retired), USDA-National Laboratory for Agriculture \\ and the Environment, Ames, IA, USA
}

\section{Overview}

Forages provide several soil benefits, including reduced soil erosion, reduced water runoff, improved soil physical properties, increased soil carbon, increased soil biologic activity, reduced soil salinity, and improved land stabilization and restoration when grown continuously or as part of a crop rotation. Ongoing research and synthesis of knowledge have improved our understanding of how forages alter and protect soil resources, thus providing producers, policymakers, and the general public information regarding which forage crops are best suited for a specific area or use (e.g. hay, grazing or bioenergy feedstock).

Forages can be produced in forestland, range, pasture, and cropland settings. These land use types comprise $86 \%$ of non-Federal United States rural lands (Table 12.1). In the United States, active forage production occurs on 22.6 million ha and is used for hay, haylage, grass silage, and greenchop (Table 12.2). Forages are used as

USDA is an equal opportunity provider and employer. This research was supported, in part, by an appointment to the Agricultural Research Service (ARS) Research Participation Program administered by the Oak Ridge Institute for Science and Education (ORISE). cover crops in several production systems, and approximately 4.2 million ha were recently planted in cover crops (Table 12.3). Currently, the highest cover crop use rates, as a percentage of total cropland within a given state, occur in the northeastern United States.

Globally, permanent meadows and pastures account for over 3.3 billion ha, greater than arable land and permanent crops combined (Table 12.4). Within all regions of the world, except Europe, permanent meadows and pastures are a greater proportion of land cover than permanent crops. Pasture management information and resources are available for countries around the world (FAO 2017a,b). As seen in Tables 12.1-12.4, forages are used globally and can provide soil benefits across varied soil and climate types.

\section{Forages Reduce Water and Wind Erosion}

Forages as part of a comprehensive soil management plan can reduce erosion, particularly, if living plants are maintained on the landscape during most of the year. Compared to agricultural fields with limited residue cover, permanent ground cover reduces soil loss (Figure 12.1). Research during the 1930 s and early 1940 s across several research sites in the United States showed that row crops

Forages: The Science of Grassland Agriculture, Volume II, Seventh Edition.

Edited by Kenneth J. Moore, Michael Collins, C. Jerry Nelson and Daren D. Redfearn.

(C) 2020 John Wiley \& Sons Ltd. Published 2020 by John Wiley \& Sons Ltd. 
Table 12.1 Land cover in non-federal rural land (2012)

\begin{tabular}{lc}
\hline Cover type & Hectares $(000 \mathrm{~s})$ \\
\hline Forest & 167300 \\
Range & 164300 \\
Crop & 146900 \\
Other rural land & 49040 \\
Conservation reserve & 18400 \\
Total rural land & 555700 \\
\hline
\end{tabular}

Source: Adapted from USDA National Resources Inventory Summary Report, August 2015, Table 2.

Table 12.2 Number of farms, hectares, and megagrams used for hay, haylage, grass silage, and greenchop in the United States and sorted by states with greatest number of hectares (2012)

\begin{tabular}{lcrr}
\hline Location & Number of farms & Hectares & \multicolumn{1}{c}{ Dry Mg } \\
\hline United States & 813583 & 22581037 & 115501930 \\
Texas & 86456 & 2052461 & 8656202 \\
Missouri & 50279 & 1356011 & 4781446 \\
Oklahoma & 32781 & 1095202 & 3411413 \\
South Dakota & 14695 & 1058781 & 3305505 \\
Nebraska & 20034 & 1007009 & 4289189 \\
Kansas & 25710 & 999594 & 3932886 \\
Wisconsin & 37020 & 970300 & 6547600 \\
Montana & 11728 & 917894 & 3609240 \\
North Carolina & 10141 & 879651 & 2847363 \\
Kentucky & 43757 & 826784 & 3771345 \\
New York & 19182 & 749385 & 4007071 \\
\hline
\end{tabular}

Source: Adapted from USDA (2012) Census of Agriculture, Table 26.

had between 98- and 1277-times as much soil loss as permanent cover (Figure 12.2). Please note that the data highlighted in Figure 12.2 were originally summarized by Browning (1951).

With increased adoption of conservation practices reducing tillage frequency and intensity, combined with increasing surface residue cover, the average erosion from agricultural land decreased (Figure 12.3). Current estimates for sheet and rill erosion from cultivated cropland are approximately $6.7 \mathrm{Mgha}^{-1} \mathrm{yr}^{-1}, 1.6 \mathrm{Mg} \mathrm{ha}^{-1} \mathrm{yr}^{-1}$ from pastureland, and $0.9 \mathrm{Mgha}^{-1} \mathrm{yr}^{-1}$ from conservation reserve land. Erosion is seven-fold higher in cultivated cropland compared to conservation reserve land. Wind erosion removes $4.9 \mathrm{Mg}$ soil ha ${ }^{-1} \mathrm{yr}^{-1}$ from cultivated cropland, $0.4 \mathrm{Mgha}^{-1} \mathrm{yr}^{-1}$ from pastureland, and $2.0 \mathrm{Mgha}^{-1} \mathrm{yr}^{-1}$ from conservation reserve land (USDA 2015). The long-term trends in wind erosion are similar to the sheet and rill erosion data (Figure 12.3).

This reduction in erosion documents a significant improvement compared to the erosion rates seen in
Figure 12.2. Figure 12.1 shows that erosion potential is a constant issue that must be addressed. Furthermore, even though average erosion rates are useful for general comparisons, generalized interpretation of these data has been long-recognized to mask variable landscape-level erosion rates (Bennett and Chapline 1928).

Similar trends in sediment reductions occur when forages are incorporated into row crops as conservation buffers (Figure 12.4) (Helmers et al. 2012) or when forages, rotational grazing, and conservation buffer strips are combined (Pilon et al. 2017). Within a no-till corn - soybean rotation, various prairie filter strip configurations reduced sediment loss by over $90 \%$. These reductions were achieved by taking either $10 \%$ or $20 \%$ of the watershed area out of crop production and placing it in conservation buffers (Helmers et al. 2012).

The prairie filter strips reduced visible ephemeral gully formation. Data from 2008-2010 are presented in Figure 12.4. All treatments in 2007 (the first year of the study), had sediment loss below $0.1 \mathrm{Mg} \mathrm{ha}^{-1}$. The study 
Table 12.3 Cover crop use in the United States by farm type, state, and proportion of cropland hectares (2012)

\begin{tabular}{lr}
\hline Cropland planted to a cover crop (excluding CRP) & Hectares \\
\hline United States & 4162264 \\
By North American Industry Classification System & 1800024 \\
Oilseed and grain farming & 543201 \\
Sugarcane farming, hay farming, and all other crop farming & 408593 \\
Dairy cattle and milk production & 376017 \\
Beef cattle and ranching & 264363 \\
Vegetable and melon farming & 312372 \\
Cotton farming & 161615 \\
Fruit and tree nut farming & \\
By State & 368851 \\
Texas & 241321 \\
Indiana & 223889 \\
Wisconsin & 180686 \\
Pennsylvania & 177004 \\
Michigan & Percent \\
By Proportion of Cropland Hectares & 3 \\
United States & 23 \\
Maryland & 16 \\
Delaware & 14 \\
Connecticut & 11 \\
Rhode Island & 11 \\
New Jersey & \\
\hline
\end{tabular}

Source: Adapted from USDA (2012) Census of Agriculture, Tables 8, 50 (national and individual states), and 68.

Table 12.4 Worldwide land cover data for arable land, permanent crops, and permanent meadows and pastures

\begin{tabular}{lrcr}
\hline & Arable land & Permanent crops & $\begin{array}{c}\text { Permanent meadows } \\
\text { and pastures }\end{array}$ \\
\cline { 2 - 4 } Location & \multicolumn{3}{c}{ Hectares (000s) } \\
\hline Worldwide & 1399212 & 152098 & 3362738 \\
Africa & 219624 & 31317 & 885058 \\
Americas & 366435 & 28287 & 817561 \\
Asia & 486772 & 75166 & 1090456 \\
Europe & 278516 & 15834 & 178996 \\
Oceania & 47865 & 1494 & 390668 \\
\hline
\end{tabular}

Source: From FAOSTAT, composition of global agricultural area, 2000-2014 average, item codes 6621, 6650, 6655.

area was previously planted to smooth bromegrass for at least ten years. Planted species in the buffer included more than 20 species. Indiangrass, little bluestem, and big bluestem were the predominate species (Helmers et al. 2012). Incorporating forages into a cropland landscape can provide large sediment reductions relative to the total area used by the forages.

\section{Forages Improve Soil Properties}

At a regional scale, soil $\mathrm{C}$ and soil aggregate stability are generally higher in non-cultivated soils than in cultivated soils, as documented for western (Kemper and Koch 1966), central plains (Haas et al. 1957), and southern US (McCracken 1959) areas. These comparisons included important data regarding fields that had been cultivated 


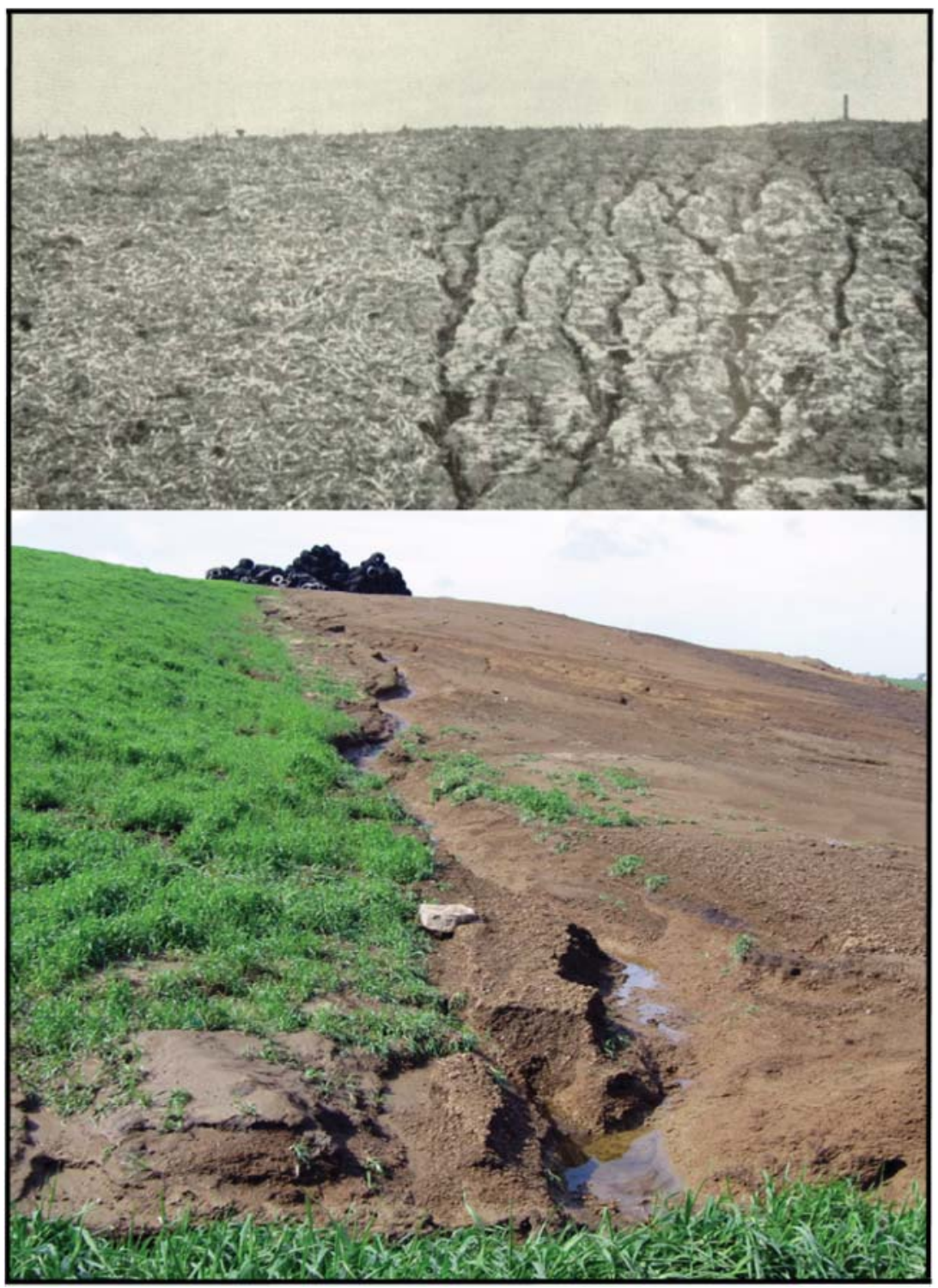

FIG. 12.1. Forages can be effective as surface mulches to reduce runoff and erosion. Top photo: Forages: The Science of Grassland Agriculture (Browning 1951). Bottom photo: Recent soil erosion in lowa (lowa NRCS, undated). Source: Figure name adapted from caption used by Browning (1951).

and fields that had never been in production. More recent data, indicates how actively managed forages can help improve numerous soil properties as discussed below. Forages can have positive effects on soil properties even on fields that remain in cultivation. Forages may help reduce site-specific variation in soil properties and processes caused by soil mismanagement, such as can occur from ephemeral gullies.

\section{Soil Carbon}

Increased soil $\mathrm{C}$ in fields planted to forages relative to other agricultural land uses was documented in a survey of the southeastern United States (Causarano et al. 2008). Within the 0 to $20-\mathrm{cm}$ layer, soil organic $\mathrm{C}$ was highest in pasture $\left(39 \mathrm{Mg} \mathrm{ha}^{-1}\right)$, followed by conservation tillage $\left(28 \mathrm{Mgha}^{-1}\right)$, and conventional tillage $\left(22 \mathrm{Mgha}^{-1}\right)$ fields (Causarano et al. 2008). The differences among 


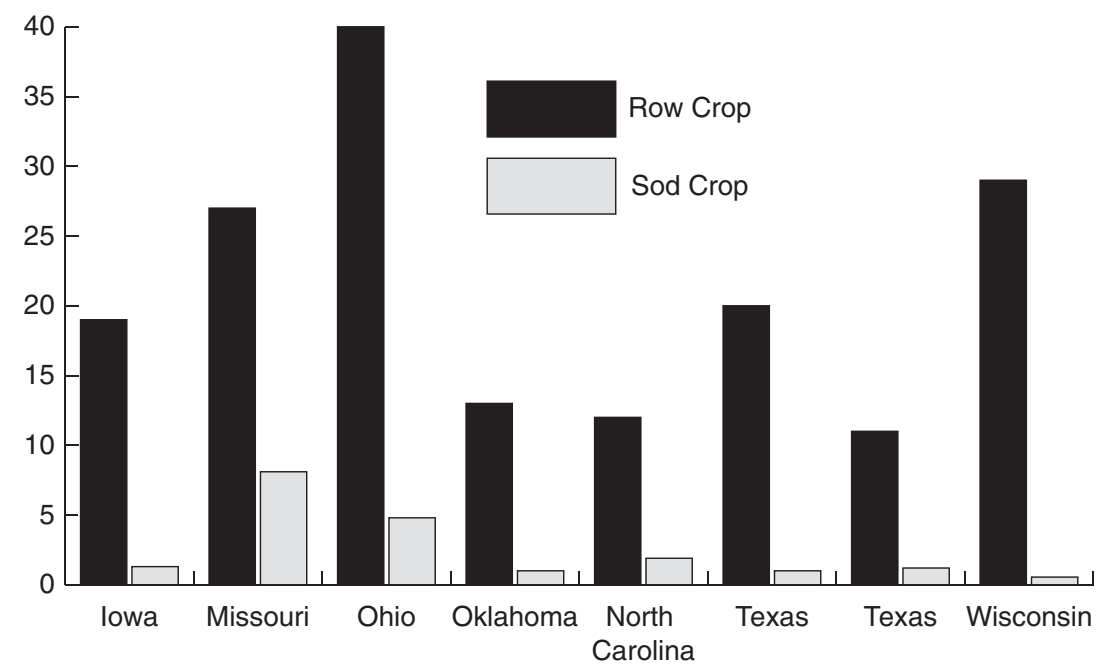

(a) Precipitation Runoff (\%)

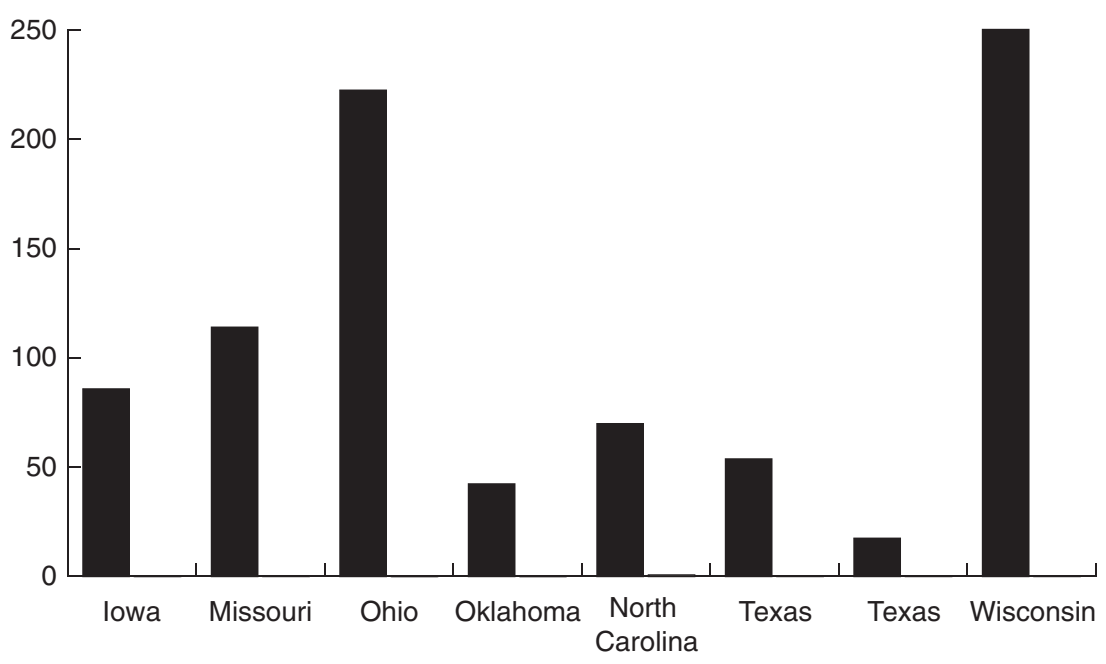

(b) Soil Loss $\left(\mathrm{Mg} \mathrm{ha}^{-1}\right)$

FIG. 12.Z. Precipitation runoff (a) and soil loss (b) data between row crop and sod across sites collected during the 1930s and 1940s in the United States. Source: Browning (1951).

these soil management systems was largest within the 0 to 5 -cm layer which had average soil organic C concentrations of 25,15 , and $7.5 \mathrm{~g} \mathrm{~kg}^{-1}$ for pasture, conservation tillage, and conventional tillage, respectively (Causarano et al. 2008). The study did not find an interaction in soil $\mathrm{C}$ effects with major land resource areas.

Similar results were reported from long-term field plots in Missouri (Veum et al. 2014). Long-term timothy pasture without manure fertilizer had approximately two-fold more soil organic $\mathrm{C}$ than soil in a moldboard-plowed continuous corn system (Table 12.5) (Veum et al. 2014).
Other treatments such as reducing tillage and adding manure also increased soil C (Table 12.5). Several studies have confirmed that incorporating forages into a rotation is an effective long-term method for increasing soil $\mathrm{C}$ (Chan et al. 2011).

If fields in long-term forage are then cultivated, some C loss will occur (Grandy and Robertson 2007; Reicosky et al. 1995). For example, one tillage activity using inversion plowing to a $20-\mathrm{cm}$ depth in a dairy-based perennial grassland farming system resulted in a $32 \mathrm{MgC} \mathrm{ha}^{-1}$ loss $(-22 \%)$ in soils collected from 


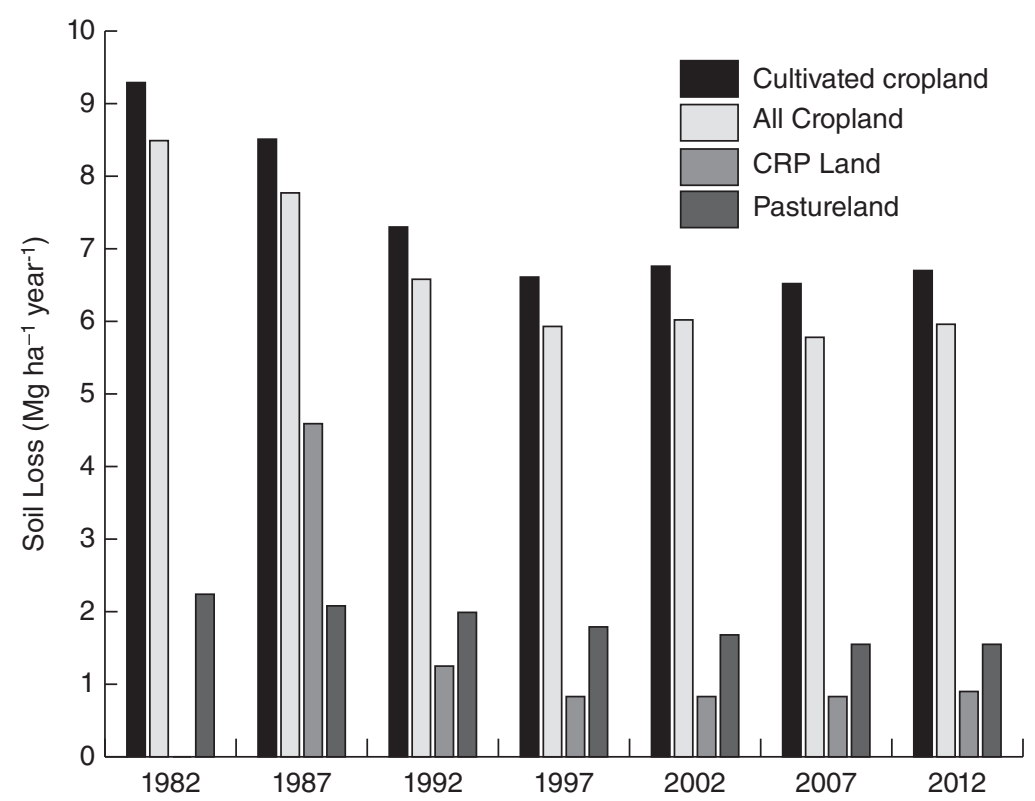

FIG. 12.3. Sheet and rill erosion from cropland, conservation reserve program (CRP) land, and pasture land in the United States. Source: USDA (2015), National Resources Inventory Report.

Table 12.5 Soil organic $C$ analyzed from long-term Sanborn Field (Boone County, Missouri, US) plots evaluated in 2008

\begin{tabular}{lllll}
\hline Crop & \multicolumn{1}{c}{ Tillage } & Fertilizer & $\begin{array}{c}\text { Year } \\
\text { established }\end{array}$ & $\begin{array}{c}\text { Soil organic } \\
\mathrm{C}\left(\mathrm{g} \mathrm{kg}^{-1}\right)\end{array}$ \\
\hline Timothy & None & Manure & 1888 & 27.4 \\
Corn & No-till & Annual N,P,K & 1950 & 22.3 \\
Timothy & None & None & 1888 & 22.2 \\
Wheat & Moldboard plow & Manure & 1888 & 19.9 \\
Corn & Moldboard plow & Manure & 1888 & 17.0 \\
Wheat & Moldboard plow & Annual N,P,K & 1888 & 15.1 \\
Corn & Moldboard plow & Annual N,P,K & 1950 & 13.3 \\
Wheat & Moldboard plow & None & 1888 & 10.3 \\
Corn & Moldboard plow & None & 1888 & 9.4 \\
\hline
\end{tabular}

Source: From Veum et al. (2014).

the 0 to 30-cm depth increment (Necpálová et al. 2013). This difference remained consistent for 2.5 years after the single tillage event and reseeding to forage. These $\mathrm{C}$ losses can be reduced if different tillage practices are used. Soils converted from long-term grass alfalfa to malt barley using a $10-\mathrm{cm}$ rototill treatment had a 1.6-fold higher soil surface $\mathrm{CO}_{2}$ flux average compared to soils remaining in grass-alfalfa. No difference in soil $\mathrm{CO}_{2}$ flux occurred between malt barley converted using no-till and long-term grass-alfalfa (Jabro et al. 2008).
Variations in soil $\mathrm{C}$ under pasture can occur by soil type, as was documented in New Zealand (Schipper et al. 2014) and Canada (Wang et al. 2014). Pasture soil profiles that had been previously surveyed were resampled throughout New Zealand (Figure 12.5). Soil C decreases in 0 to $30-\mathrm{cm}$ soil samples were found in Allophanic and Gley soils, with reductions of approximately $1.4 \mathrm{~kg} \mathrm{C} \mathrm{m}^{-2}$ and $0.8 \mathrm{~kg} \mathrm{C} \mathrm{m}^{-2}$, respectively (Schipper et al. 2014). These $\mathrm{C}$ decreases could have occurred due to increased artificial drainage on the inherently poorly-drained Gley 


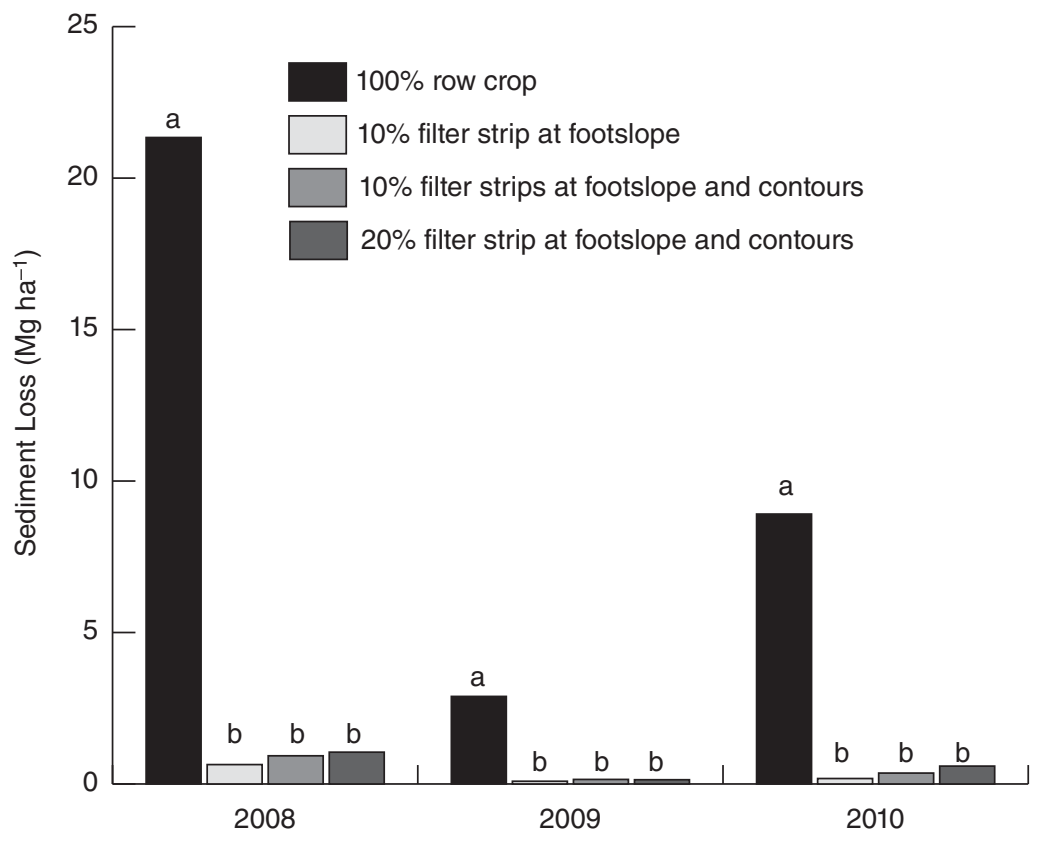

FIG. 12.4. Prairie filter strips effect on reducing sediment loss from no-till corn-soybean fields in lowa (Helmers et al. 2012).

soils and higher than anticipated soil C degradation in Allophanic soils (Schipper et al. 2014). Soil C differences were not seen in soils under forages used for either dairy or drystock production. Increases in soil C occurred more frequently on sloped fields, compared to flat fields, due to reduced erosion on the sloped fields (Schipper et al. 2014).

Grazing intensity can also affect soil C concentrations. In the southeastern United States, surface soils $(0$ to $15 \mathrm{~cm}$ ) frequently trafficked by grazers contained 1.3-fold more soil $\mathrm{C}$ than soil under non-harvested forages. The frequently trafficked areas also had 1.6-fold more soil $\mathrm{C}$ than hayed forages (Franzluebbers and Stuedemann 2009). This trend was reversed in southern Brazil. Compared to an area grazed to a sward height of $10 \mathrm{~cm}$, a nongrazed area had 1.1-fold higher soil carbon stocks at a depth of $30 \mathrm{~cm}$ (Carvalho et al. 2010b). At other research sites in the southeastern US, lower grazing intensity increased particulate organic carbon fractions 1.2-fold compared with higher grazing intensities as a greater amount of plant matter remained in the field (Silveira et al. 2013). The root mass available to potentially contribute to soil $\mathrm{C}$ can be increased by grazing (Russell and Bisinger 2015) or by maintaining different forages with a variety of rooting depths (McNally et al. 2015).

Surface soil C, such as collected from 0 to $15 \mathrm{~cm}$, tends to increase under permanent forage compared to other cropping systems. Holding other landscape variables constant, these soil $\mathrm{C}$ differences between forage and continuous field crop systems is largest when comparing two treatments with a larger range in soil disruption, such as was seen in Table 12.5 for soils collected from 0 to $10 \mathrm{~cm}$. Site-specific factors can change the magnitude of the soil $\mathrm{C}$ benefit from forages. For example, soil C changes in integrated crop-livestock systems in Brazil depended on several factors including crops grown, climatic conditions, condition of land transitioned, and amount of time in the management system (Carvalho et al. 2010a; Salton et al. 2014).

\section{Soil Aggregation}

Soil aggregation increases under permanent forage when compared to forage in a cropping rotation or continuous crop production system (Figure 12.6) (Harris et al. 1966). The soil aggregates formed under forages tend to be larger in size, such as greater than 1 or $2 \mathrm{~mm}$ in diameter (Jokela et al. 2011, Angers 1992, Wilson et al. 1948). These larger aggregates are also important sites for increasing soil C (Grandy and Robertson 2007). Seasonal variability in soil aggregation occurs (Bach and Hofmockel 2016; Rasiah and Kay 1994; Perfect et al. 1990). Soil aggregate sizes are reduced when a soil under permanent forage is converted to continuous crop production (van Bavel and Schaller 1951). The difference in 


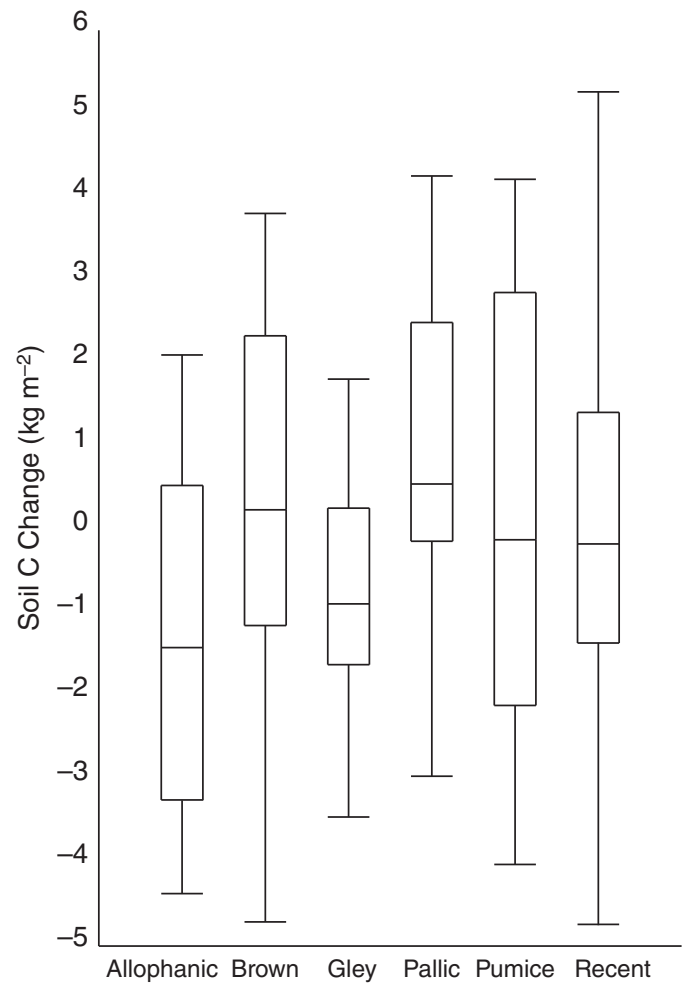

FIG. 12.5. Changes in soil $\mathrm{C}$ by soil order for long-term forage systems in New Zealand for 0 to 30-cm samples (Schipper et al. 2014). Figure generated using supplemental data provided in article. Sample size from left to right: $32,27,25$, $32,15,19$.

soil aggregate sizes between cultivated and non-cultivated soils can depend on the method used to evaluate soil aggregates. Differences are most pronounced in a test simulating slaking (Elliott 1986).

Across the United States, a 2014 survey of rangeland soils documented a range of aggregate stabilities when evaluated using an in-field soil aggregate stability slake test (Figure 12.7) (USDA NRCS 2014). Soils with a rating of 4 or less were unstable in water. Figure 12.7 shows aggregate stability for rangeland soils plotted by the number of rangeland acres reported in the 2012 National Resources Inventory (USDA 2015). Soils in Arizona, Nevada, and New Mexico were the least stable. These three states also had the highest percentages of bare ground, with approximately $38 \%, 29 \%$, and $26 \%$, respectively (USDA NRCS 2014). Rangeland practices that promote forage cover and reduce bare ground, such as avoiding overgrazing, may help reduce the erosion potential of these soils.
Forage species can impact soil aggregation. Changes in soil wetting and drying conditions caused by smooth bromegrass growth reduced soil aggregate stability compared with a control soil without bromegrass (Caron et al. 1992). Forage species with greater root mass can increase soil aggregation $(>0.5 \mathrm{~mm},<2.0 \mathrm{~mm}$ ) (Stone and Buttery 1989). In an 80-day laboratory experiment using Brookston clay loam soil, soil wet aggregate stability ranged from 34 to $45 \%$ across nine forage species. Higher wet aggregate stability occurred in reed canarygrass (45\%) and produced $17.8 \mathrm{~g}$ of root dry weight (Stone and Buttery $1988)$. Water stable aggregates $(>0.25 \mathrm{~mm})$ in an 84 -day experiment using coastal plain Georgia soils tended to be similar to control soils under field $\mathrm{pH}$ conditions for warm- and cool-season plants (Karki and Goodman 2011).

\section{Water Infiltration}

Forages increase water infiltration into the soil by increasing the amount of roots in the soil and providing canopy interception for rainfall (Angers and Caron 1998; Meek et al. 1989 1992, Miller et al. 1963). The magnitude of these changes can be affected by several factors, including soil type, number of years following management changes, and yearly management activities.

Following four growing seasons of alfalfa, water infiltration rate was higher in no traffic and minimal traffic areas compared to alfalfa areas that received more frequent traffic (Meek et al. 1989). Compared to baseline conditions, increases in infiltration rates were 2.6-fold for no traffic, 2.2-fold for preplant traffic, 1.6-fold for traffic reflecting current grower practices, and 1.2-fold for repeated traffic activities (Meek et al. 1989). In orchard soils, cumulative infiltration was reduced by approximately one-half between traveled and non-traveled areas, and larger infiltration rates occurred in soils with cover crops than in those without (Miller et al. 1963). Site-specific preferential flow can also affect infiltration under forages (Harman et al. 2011).

Conversely, cover crops grown as part of a corn-soybean rotation did not have consistent water infiltration after three years (Kaspar et al. 2001). Instead, wheel traffic affected infiltration to a greater extent than the presence of oat or rye. Averaged across all three years, areas without traffic allowed 1.85-fold higher infiltration than tracked areas $\left(20.3 \mathrm{~g} \mathrm{~m}^{-2} \mathrm{~s}^{-1}\right.$ vs. $10.9 \mathrm{~g} \mathrm{~m}^{-2} \mathrm{~s}^{-1}$ ) (Kaspar et al. 2001). The potential soil structural benefits from growing cover crops for one year may be masked by the machinery traffic required to manage the cover crops (Rücknagel et al. 2016).

Animal hoof action is another form of site traffic that can compact soils and reduce water infiltration rates (Russell and Bisinger 2015; Cuttle 2008). Bare soils are prone to being compacted compared to soils with at least $10 \mathrm{~cm}$ sward height, and these compacted soils will have 


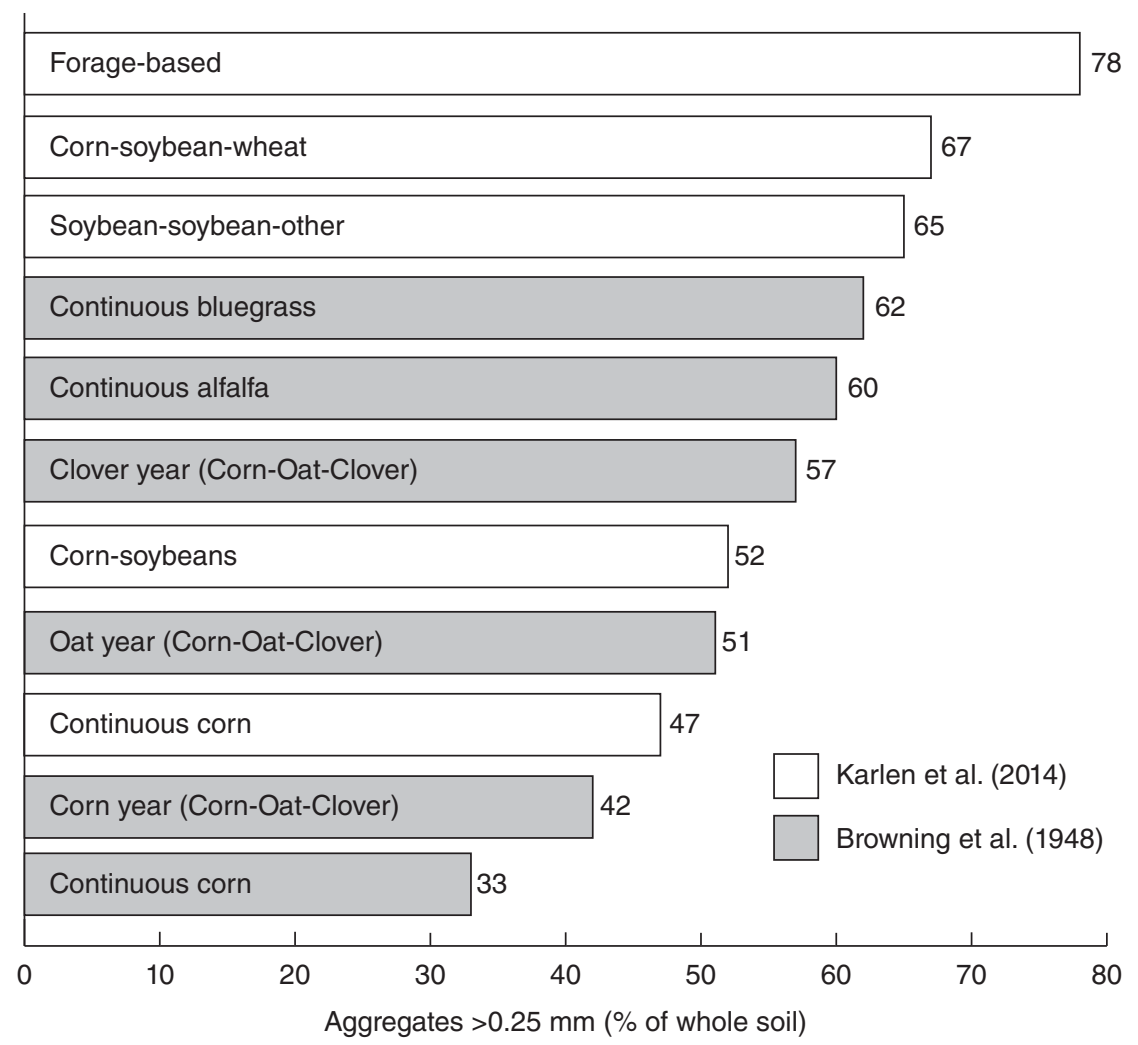

FIG. 12.G. Aggregate stability data for several cropping systems collected from lowa (Browning et al. 1948, Karlen et al. 2014), Indiana, Missouri, and Ohio (Karlen et al. 2014). Source: Data from Karlen et al. (2014) for 0 to 5 -cm samples.

lower water infiltration rates (Russell and Bisinger 2015). Grazed soils with sward heights of $10 \mathrm{~cm}$ or greater did not have greater phosphorus (P) loss or runoff volume compared to nongrazed areas (Russell and Bisinger 2015). Walking cattle can exert pressures on the soil potentially three times higher than an unloaded tractor. The greatest amounts of soil compaction occur close to the soil surface due to the smaller surface area of hooves compared to tractor tires. Depending on pasture size, length of grazing, and pasture location, each unit of soil could be walked on 10 times during a 140-day grazing season (Russell and Bisinger 2015).

\section{Soil Microbial and Biological Activity}

Forages increase soil microbial activity and abundance. Long-term pasture soils had higher values for several soil microbial indicators, particularly for soils collected from 0 to 2.5-cm depth (Haynes 1999). Compared to long-term row-cropped land, long-term pasture had an estimated two-fold higher organic C, 1.5-fold higher microbial quotient, 1.7-fold higher metabolic quotient, 3.5-fold higher fluorescein diacetate (FDA) hydrolytic activity, and five-fold higher acid phosphate activity (Haynes 1999).

Similar microbial differences occurred between long-term corn and pasture plots (Veum et al. 2014) and between vegetable crops and pasture (Bandick and Dick 1999). Timothy plots had 2.5-fold and 7.9-fold higher dehydrogenase activity than wheat and corn plots, respectively. Phenol oxidase activity under timothy was 2.7-fold higher than wheat and two-fold higher than corn (Veum et al. 2014). Pasture soils (0 to 20-cm) had between 1.7- and 3.6-fold higher FDA hydrolysis compared to vegetable crop rotations in western Oregon (Bandick and Dick 1999). Permanent fescue had higher enzyme activities than winter fallow plots in western Oregon for $\beta$-galactosidase (1.3-fold higher), amidase (1.4-fold), deaminase (1.04-fold), invertase (1.3-fold), and urease (1.4-fold). At the same research location, cover crops included in the vegetable rotation had similar enzyme activities as the fescue plots (Bandick and Dick 1999). 


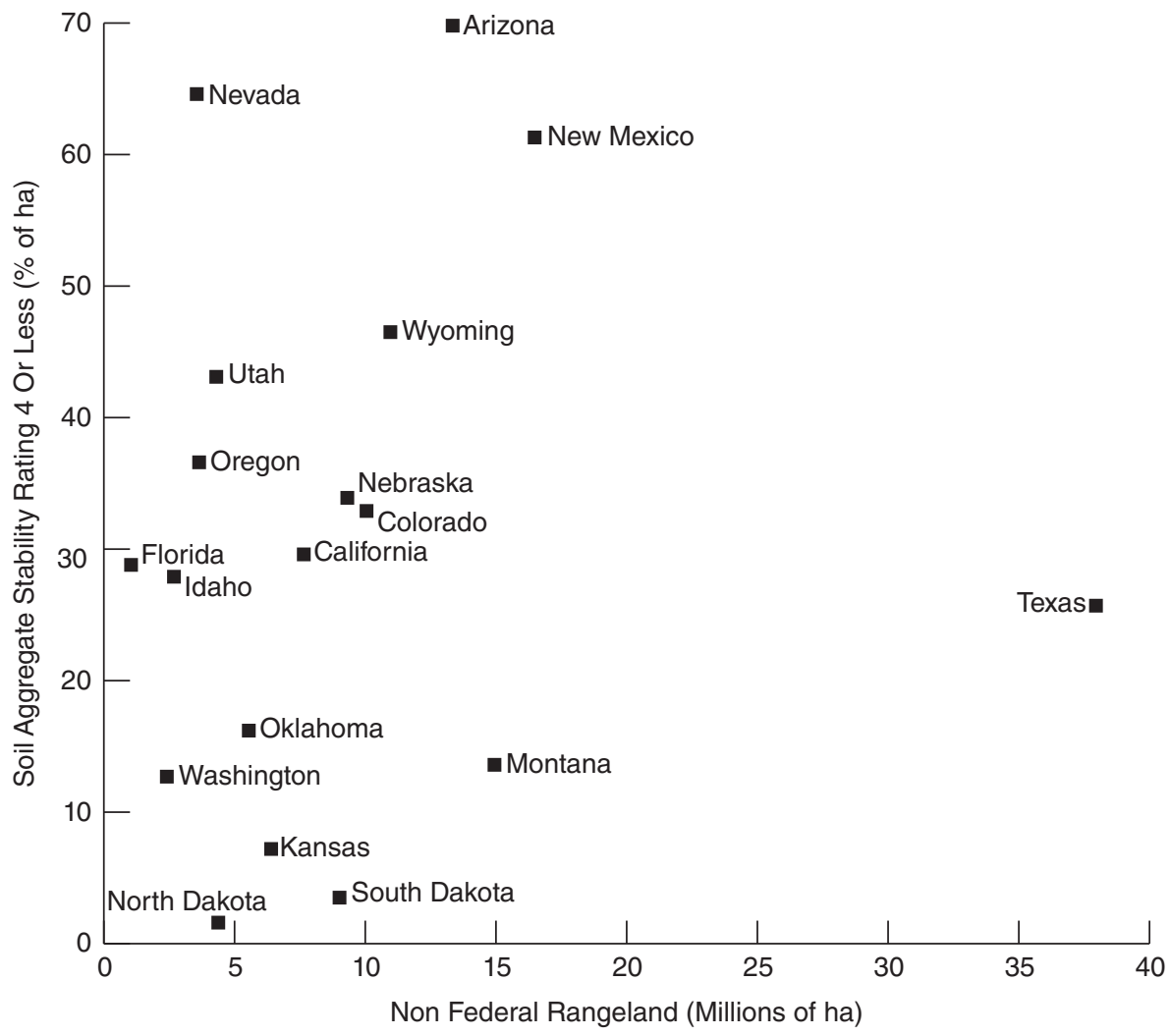

FIG. 12.7. Soil aggregate stability ratings for rangeland soils in the United States. Note: A rating of four or less indicates at most $25 \%$ of soil remains on the sieve following aggregate stability test. Source: USDA National Resources Inventory (2014) Rangeland Resource Assessment.

Forage species influence soil fauna differences. Perennial ryegrass tended to support more herbivorous invertebrates compared to chicory, red clover, and white clover. These invertebrates included greater abundances of herbivorous nematodes and certain Collembola superfamilies. Higher abundances occurred in perennial ryegrass fertilized with $200 \mathrm{~kg} \mathrm{Nha}^{-1} \mathrm{yr}^{-1}$ compared to ryegrass plots receiving $80 \mathrm{~kg} \mathrm{Nha}^{-1} \mathrm{yr}^{-1}$. The other three forages supported higher populations of decomposer invertebrates compared to perennial ryegrass (Crotty et al. 2015). White clover had between 1.7- and 2.2-fold higher earthworm abundance compared to the other forages. Total nematode populations were consistent across the forages (Crotty et al. 2015).

Quantifying interactions among soil, forage roots, soil enzymes, and soil organisms requires substantial research to properly evaluate direct and indirect effects (Crotty et al. 2015). For example, soil pH can influence soluble $\mathrm{P}$ cycling, as lower $\mathrm{pH}$ forage soils tend to have lower activities of phosphodiesterase and higher labile organic P concentrations (Turner and Haygarth 2005). In lower $\mathrm{pH}$ soils, fungi tend to occur in greater abundance than bacteria. Subtle linkages between soil microbial activity and nutrient availability could affect forage soil management. Additional opportunities exist for increased understanding of and linking soil biology and plant species to achieve disease-suppressive pasture systems (Dignam et al. 2016).

Three years of forage growth followed by spring wheat and winter barley growth indicated soil fungal community effects could be detected during the cereal crop growth (Detheridge et al. 2016). The anti-fungal isothiocyanates released by forage radish during decomposition did not reduce arbuscular mycorrhizal fungi colonization in maize roots (White and Weil 2010). Compared to no cover crop, cereal rye increased AMF colonization $12-16 \%$ in three 
of six site-years when measured at V4 corn growth stage, with no cover crop effect found at V8 (White and Weil 2010).

\section{Nutrient Cycling}

Long-term crop rotations that include forages, such as alfalfa, are well known as a method for maintaining and increasing crop yields while reducing external $\mathrm{N}$ inputs (Osterholz et al. 2017; Ross et al. 2008; Page and Willard 1947). Cover crops, such as forage radish and winter pea may help cycle nitrogen $(\mathrm{N})$ and $\mathrm{P}$ for subsequent crops (White and Weil 2011; Jahanzad et al. 2016). Cereal rye, a widely planted cover crop, might not cycle agronomically important amounts of $\mathrm{N}$ for future crops, but it often does reduce soil $\mathrm{N}$ loss (Jahanzad et al. 2016; Pantoja et al. 2016).

Nitrification rates of forages vary by species and cultivar (Bowatte et al. 2015). Forage species and cultivars with a low rate of soil nitrification may help reduce soil $\mathrm{N}$ losses, and in combination with high biomass production could be useful management tools (Bowatte et al. 2015). An analysis of 126 cultivars and 26 species used in temperate grasslands indicated variation between and within cultivars. These findings highlighted the potential use of additional breeding selection for specific characteristics, in addition to improving nitrification test methodology (Bowatte et al. 2015).

Forage grazing introduces $\mathrm{N}, \mathrm{P}$, and $\mathrm{K}$ to the soil through animal waste, as approximately $70-90 \%$ of nutrients will be recycled by animals and not removed from the field (Haynes and Williams 1993). Nutrient loss from the soil may occur due to an imbalance in plant uptake and an excess of animal supplied fertilizer. Across sixteen grasses common to New Zealand, Moir et al. (2012) reported a range of $\mathrm{N}$ leaching losses from applied dairy cow urine. Perennial ryegrass, tall fescue, and kentucky bluegrass had lower plant $\mathrm{N}$ uptake and increased soil water $\mathrm{N}$ leaching (Moir et al. 2012). Pairing perennial ryegrass with white clover in pasture systems, along with nitrification inhibitors and fungal inoculation may help reduce $\mathrm{N}$ loss from perennial ryegrass systems and reduce the need for $\mathrm{N}$ fertilizer applications (Andrews et al. 2011).

\section{Combined Soil Health Effects of Forages}

While soil physical, chemical, and biologic effects from forages can be measured and interpreted separately, forage systems can systematically change all of these properties (Jokela et al. 2011) (Table 12.6). Soil quality or soil health assessments measure multiple soil physical, chemical, and biologic properties and aggregate these values to create a system-level assessment of soil function. Several different methods can be used for this process, including the soil management assessment framework (SMAF) (Andrews et al. 2004), the soil conditioning index (SCI) (Zobeck et al. 2007), the comprehensive assessment of soil health (CASH) (Moebius-Clune et al. 2016), and

Table 12.6 Soil physical, chemical, and biologic properties between pasture and other cropping systems after 18 years from Arlington, WI

\begin{tabular}{|c|c|c|c|c|c|}
\hline \multirow[b]{2}{*}{ Sampling depth $(\mathrm{cm})$} & \multirow[b]{2}{*}{ Units } & \multicolumn{2}{|c|}{ Pasture } & \multicolumn{2}{|c|}{$\begin{array}{c}\text { Other cropping } \\
\text { systems }\end{array}$} \\
\hline & & $0-5$ & $5-20$ & $0-5$ & $5-20$ \\
\hline $\mathrm{pH}$ & & 6.20 & 6.50 & 6.66 & 6.63 \\
\hline $\mathrm{P}$ & $\mathrm{mg} \mathrm{kg}^{-1}$ & 49.8 & 36.0 & 54.8 & 42.1 \\
\hline K & $\mathrm{mg} \mathrm{kg}^{-1}$ & 163 & 75 & 173 & 90 \\
\hline Total organic C & $\mathrm{g} \mathrm{kg}^{-1}$ & $33.6^{a}$ & 22.4 & 24.5 & 21.7 \\
\hline Total N & $\mathrm{g} \mathrm{kg}^{-1}$ & $3.40^{a}$ & 2.10 & 2.36 & 2.14 \\
\hline Active C & $\mathrm{mg} \mathrm{kg}^{-1}$ & $2350^{a}$ & 1380 & 1850 & $1640^{a}$ \\
\hline Potentially mineralizable $\mathrm{N}$ & $\mathrm{mg} \mathrm{kg}^{-1}$ & $61.2^{a}$ & 24.4 & 34.5 & 24.4 \\
\hline Total microbial biomass & $\mathrm{nmol} \mathrm{kg}^{-1}$ & $523^{a}$ & 193 & 194 & 131 \\
\hline Bulk density & $\mathrm{kg} \mathrm{cm}^{-3}$ & 1.24 & 1.42 & 1.21 & 1.41 \\
\hline Water content & $\mathrm{kg} \mathrm{kg}^{-1}$ & $0.29^{a}$ & 0.23 & 0.27 & 0.26 \\
\hline Water stable aggregates $(2-8 \mathrm{~mm})$ & $\mathrm{g} \mathrm{kg}^{-1}$ & $649^{a}$ & $639^{a}$ & 332 & 443 \\
\hline Water stable aggregates $(0.25-2 \mathrm{~mm})$ & $\mathrm{g} \mathrm{kg}^{-1}$ & 240 & 234 & 439 & $413^{a}$ \\
\hline
\end{tabular}

Source: Jokela et al. (2011).

${ }^{a}$ Noted statistical significance for difference between pasture and other cropping systems at a given depth. Symbol next to higher value. See Jokela et al. (2011) for details. 
several other tests including those offered by commercial laboratories.

Generally, these assessment methods yield similar results. High-functioning soils are indicated as such across the methods used, though there can be variation in the magnitude of differences found among calculation methods (Congreves et al. 2015; Karlen et al. 2017; Zobeck et al. 2008). Soil quality index calculation methods for cropping systems in Brazil indicated soils under pasture tended to have an intermediate level of soil functioning below the highest functioning native vegetation and the lowest functioning sugarcane production. Several calculation methods also indicated pasture and sugarcane production had similar functioning soils (Cherubin et al. 2016). The difference in results occurred depending on which soil properties were included in a given index calculation and how values were added together (Cherubin et al. 2016).

Forages in rotations with reduced tillage or in permanent pasture tend to have higher soil quality index values compared to other systems (Karlen et al. 2014; Veum et al. 2014, Zobeck et al. 2007). Perennial timothy plots receiving manure applications had approximately 1.5 -fold higher SMAF scores than moldboard plow corn receiving no fertilizers. Timothy plots without manure had 1.4 -fold higher SMAF scores than the same corn treatment (Veum et al. 2014). Forage-based rotations throughout sites in the Midwest US had 1.1-fold higher soil quality index scores compared to continuous corn sites (Karlen et al. 2014).

Increased soil quality index values do not always occur, however, especially if all comparison sites are inherently highly productive (Jokela et al. 2011). For example, a comprehensive evaluation of several cropping systems in Wisconsin identified differences in soil physical, chemical, and biologic properties. Pasture soils had larger $>2 \mathrm{~mm}$ water stable aggregates, higher $\mathrm{C}$ and $\mathrm{N}$ measurements, and similar $\mathrm{P}$ and $\mathrm{K}$ soil concentrations. Other cropping systems had higher water stable aggregates $<2 \mathrm{~mm}$, potentially due to more frequent soil disruption that reduced larger aggregate formation. The other cropping systems tested included continuous corn, grain rotations, forage systems, and a grass-legume pasture (Jokela et al. 2011). Most of the differences found between pasture soils and the other cropping systems occurred in the 0 to $5-\mathrm{cm}$ depth range, though the aggregate stability difference was also seen at samples collected from 5 to $20-\mathrm{cm}$.

\section{Saline Seeps}

Forages are effective for controlling the soil chemical management problem of saline seeps. Saline seeps occur in areas where water flows through the soil accumulating salts in the soil solution until it comes into contact with some form of impermeable layer and gradually moves back to the soil surface. This series of steps often occurs in downslope soil gradients. Then, as water evaporates from the soil surface, excess salts are left behind in the soil rooting zone (Halvorson and Richardson 2011; Miller et al. 1981). These soils can be classified as saline soils if the electrical conductivity is greater than $4 \mathrm{dS} \mathrm{m}^{-1}$, but soil electrical conductivity levels do not need to reach $4 \mathrm{dS} \mathrm{m}^{-1}$ for yields to be reduced (Steppuhn et al. 2005; Maas and Grattan 1999).

Forages can help manage saline seeps by lowering the water table through increased plant transpiration. One well-known forage for managing saline seeps is alfalfa because the species has a deep rooting system and can use over $600 \mathrm{~mm}$ of soil water after several years of growth (Halvorson and Richardson 2011). Other potential forages include tall wheatgrass, slender wheatgrass, altai wildrye, and tall fescue (Franzen 2013; McCauley and Jones 2005). This water use lowers soil water content throughout the soil surface profile. Forages grown at soil water recharge and discharge areas would be most beneficial to reduce the water table across the entire area of the seep's formation. Rainfall will further help flush surface salts away from the surface in the location of the saline seep.

Plant breeding continues to develop more salt-tolerant crops that are well suited to managing saline seeps. Some alfalfa varieties were suitable for growing in $15.6 \mathrm{dS} \mathrm{m}^{-1}$ soils, the highest tested rate (Steppuhn et al. 2012). Beyond an individual saline seep, maintaining permanent vegetative cover on agricultural soils can help reduce saline soil risks at a landscape scale (Wiebe et al. 2007).

\section{Selecting Forages for a Management Goal}

Forages can serve many purposes, each of which modifies soils to a different extent. For example, forages can be grazed by livestock or harvested and fed to livestock. The plant material has the same end use, but the type, frequency, and other harvest factors affecting the soil resource are very different. Forages can be used as cover crops or incorporated into a crop rotation. For restoring saline soils, forages can be used to modify water dynamics and reduce soil salinity over time. Forages can also be used to restore cover to landscapes as part of ecologic restoration. When placed within a cropping system as a conservation buffer, forages help reduce sediment loss. Furthermore, the specific forage species that will be best suited to address a specific management goal will differ. Two examples illustrating the selection of forages to address specific management goals and the resultant forage-soil interactions are described below.

\section{Cover Crops}

Farmers report several motivations for using cover crops to improve soil physical, chemical, and biologic properties (Table 12.7). This includes their ability to improve soil health through changes in various soil carbon and 
Table 12.7 Farmer reported motivations for using cover crops

\begin{tabular}{lc}
\hline Motivating factors & \% of respondents \\
\hline Increase overall soil health & 87 \\
Increase soil organic matter & 83 \\
Reduce soil compaction & 76 \\
Reduce soil erosion & 76 \\
Scavenge nitrogen & 59 \\
Provide another nitrogen source & 57 \\
Choose diverse rooting systems & 51 \\
\hline
\end{tabular}

Source: From SARE/CTIC 2015-2016 Cover Crop Survey, p. 15, (SARE 2017a).

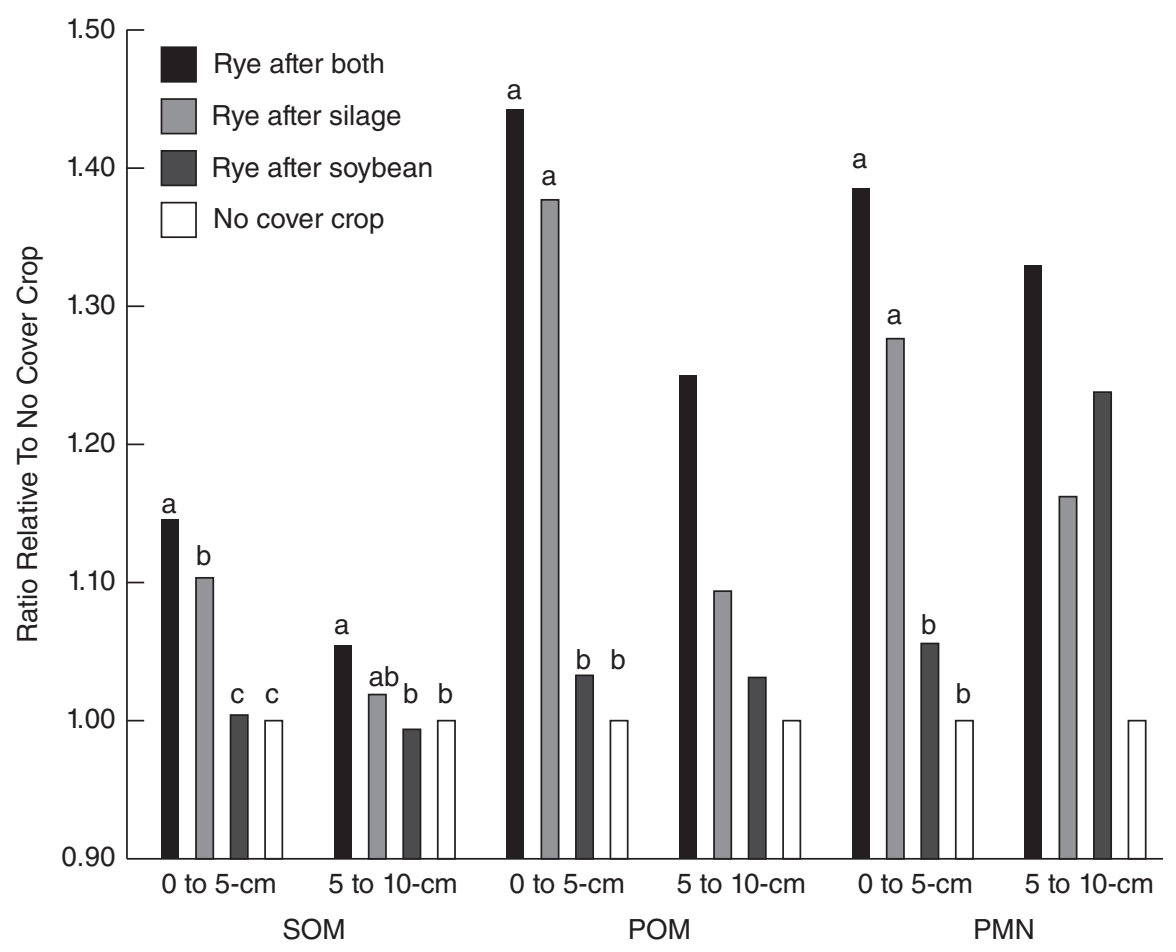

FIG. 12.8. Cover crop effects on soil organic matter (SOM), particulate organic matter (POM), and potentially mineralizable nitrogen (PMN) in a corn silage system measured after 10 years (Moore et al. 2014). Note: Letters indicate statistically significant differences within a given depth and soil property.

nitrogen fractions (Figure 12.8). Forages can also be incorporated into prairie strips which have been shown to reduce runoff and soil erosion (Schulte-Moore et al. 2020). As part of a crop rotation, long-term data evaluating winter rye as a cover crop indicated no reduction in subsequent crop yields (Basche et al. 2016). However, there were significant soil changes that included a 10 to $11 \%$ increase in field capacity soil water content and a
21-22\% increase in plant available water (Basche et al. 2016). As reported by cover crop survey participants, the most widely planted cover crop is cereal rye, followed by forage radish (Table 12.8).

In recent years, several resources have been developed to help producers select appropriate forage species for a variety of management goals including their use as cover crops. Both state- and regionally-specific decision tools 
Table 12.8 Farmer reported cover crops used in the United States

\begin{tabular}{lcc}
\hline & $\begin{array}{c}2015 \\
\text { Planted }\end{array}$ & $\begin{array}{c}2016 \\
\text { Projected }\end{array}$ \\
\cline { 2 - 3 } Crop & \multicolumn{2}{c}{ Hectares } \\
\hline cereal rye & 75726 & 88082 \\
radish & 39589 & 49060 \\
winter wheat & 33408 & 30588 \\
rapeseed & 23235 & 24842 \\
annual ryegrass & 20256 & 26471 \\
oat & 20227 & 25670 \\
crimson clover & 19123 & 21005 \\
\hline
\end{tabular}

Source: From SARE/CTIC 2015-2016 Cover Crop Survey, p. 21-27 (SARE 2017a).

have been developed for the Midwest (MCCC 2017), Pacific Northwest (USDA NRCS 2016), Pennsylvania (Penn State n.d.), and New York (Cornell University 2010). Information resources such as factsheets and other online Extension materials are also available from individual states or nationwide (SARE 2017b). An example of the selection process for choosing cover crops to meet specific soil and forage goals is presented in Table 12.9. Using the Midwest Cover Crops Council decision tool, different cover crops were suggested for goals such as soil building, forage harvest, or grazing. The specific forages recommended demonstrate the range of plant species available for providing forage and improving soil conservation.

Cover crops can also be incorporated as permanent ground cover between crop rows where they function as a living mulch. This practice is more common for fruit and tree crops, though corn was successfully intercropped

Table 12.9 Midwest Cover Crops Council decision-tool selections for cover crops in row crop production combining goals of soil builder, forage harvest value, and good grazing ${ }^{a}$

\begin{tabular}{ll}
\hline Cover crop $^{b}$ & \multicolumn{1}{c}{ Locations $^{c}$} \\
\hline Alfalfa & IL, MI, MN, OH, ON \\
Annual ryegrass & IL, MO, OH \\
Barley & KS \\
Berseem clover & IN, OH \\
Crimson clover & IL, IN, MI, OH \\
Oat & IL, ON \\
Pearl millet & IL, IN, KS, MO, OH, WI \\
Red clover & IL, IN, MI, OH, ON, WI \\
Rye & IA, KS, MI, MN, MO, ON, WI \\
Sorghum-sudangrass & IA, IN, KS, MN, OH, ON, WI \\
Sudangrass & IA, IL, IN, MI, MN, OH, WI \\
Triticale & IA, KS, MO \\
Winter wheat & IA, KS, MO \\
\hline
\end{tabular}

Source: Midwest Cover Crops Council Row Crop Decision Tool (MCCC 2017).

${ }^{a}$ Generated for each state using all counties average.

${ }^{b}$ Listed cover crops are those that received "excellent" ratings in all three goals or "excellent" ratings in at least two of three goals and "very good" ratings in one of three goals. These are not the only cover crops that will meet producers' needs in these locations.

'Iowa (IA), Illinois (IL), Indiana (IN), Kansas (KS), Michigan (MI), Minnesota $(\mathrm{MN})$, Missouri $(\mathrm{MO})$, Ohio $(\mathrm{OH})$, Ontario $(\mathrm{ON})$, Wisconsin (WI). 
with kura clover in Wisconsin (Ziyomo et al. 2013). Having sufficient plant available soil water, however, can be a major management challenge and result in significant crop yield loss if the cover crop and cash crop are both growing simultaneously (Qi et al. 2011; Ziyomo et al. 2013).

Water-induced yield losses might not occur every year (Bartel et al. 2017) and can also be reduced if some portion of the living mulch is terminated (Kumwenda et al. 1993). Planting drought-resistant crops into living mulches can overcome these potential yield losses. Drought-resistant corn hybrids had approximately three-fold higher yields when grown in living or killed kura clover mulch treatments compared to droughtsusceptible corn varieties (Ziyomo et al. 2013).

From a soil-health perspective, fields with living mulches may support higher soil fungal populations and often have higher litter decomposition rates compared to fields without living mulches (Nakamoto and Tsukamoto 2006). Living mulches may also allow higher rates of corn stover removal for bioenergy and bio-product feedstock due to increased soil cover from the permanent groundcover (Bartel et al. 2017).

\section{Site Restoration}

When restoring an entire site, such as occurs in mineland reclamation, forages must survive in a wide range of soil conditions. First, the soil itself must be deep enough to establish plants. Plant production can depend on soil depth of the restoration site and the type of underlying material being remediated. For example, greater soil replacement, such as up to $1.5 \mathrm{~m}$ of new material, can increase plant growth over acid spoil materials and sodic materials, but may have less of an impact on other spoil materials (Barth and Martin 1984). Fast-establishing plant species can also help reduce competition by other non-planted species (Wick et al. 2011). Numerous forage species are suitable for mineland reclamation because they can survive a range of soil conditions. The examples, presented in Table 12.10 include species that have the potential for mineland reclamation and a forage source.

Forages provide multiple benefits in site restoration. Potential contaminant migration from the site can be reduced with forages that limit surface erosion and water runoff (Pilon-Smits 2005). Forages can also stimulate soil microbial degradation of contaminants, including fescue and ryegrass (Pilon-Smits 2005). Grazing forages grown in site restoration locations, such as from saline soils, requires evaluating plant uptake that could harm animal health (Masters et al. 2007). The forages should be tested and compared to recommended tolerance ranges to ensure animal health (National Research Council 2005).

\section{Landscape Effects of Forages on Soil}

The magnitude of forage effects on larger landscape processes is site specific. The cover management factor (C-factor) used in soil erosion calculations across Europe could be reduced using forages as cover crops (Panagos et al. 2015). This reduced factor would lead to reduced soil erosion estimates from a given location. Cover crops could reduce this $\mathrm{C}$-factor more than $8 \%$ in some locations, and less than $0.5 \%$ in others (Panagos et al. 2015). For comparison, changing tillage practices could reduce the C-factor up to $30 \%$ in some locations and less than $5 \%$ in others (Panagos et al. 2015). These modeled data are useful for demonstrating how forages can be helpful in reducing landscape level soil erosion, and how forages are one piece of larger management changes that can help reduce erosion.

Forages in conservation buffers were shown to be effective in reducing ephemeral gully formation (Helmers et al. 2012). Ephemeral gully erosion is implicated in increasing the sedimentation of reservoirs (Fox et al. 2016). However, larger watershed level impacts of conservation buffers can vary by watershed characteristics. Stream sediments can come from several sources including channel and bank erosion, as well as previously eroded sediments that become re-suspended (legacy sources) (Fox et al. 2016; Tomer and Locke 2011).

Increased nutrient and sediment losses in the Lincoln Lake (Arkansas and Oklahoma) watershed evaluated between 1992 and 2004, resulted from a combination of increased urbanization and increased $\mathrm{N}$ applications to pasture areas (Chiang et al. 2010). Variations occurred among the three sub-watersheds evaluated. In two of the three sub-watersheds, land use change increased total $\mathrm{N}$ losses to a greater extent than pasture management $\left(3.8-5.1 \mathrm{~kg} \mathrm{Nha}^{-1}\right.$ vs $\left.1-1.7 \mathrm{~kg} \mathrm{Nha}^{-1}\right)$. In the other sub-watershed, pasture management had a higher impact on $\mathrm{N}$ losses compared to urbanization $\left(4.3 \mathrm{~kg} \mathrm{~N} \mathrm{ha}^{-1}\right.$ vs $0.8 \mathrm{~kg} \mathrm{Nha}^{-1}$ ). In this sub-watershed, $\mathrm{N}$ applications to pasture increased from $147 \mathrm{~kg} \mathrm{Nha}^{-1}$ to $332 \mathrm{~kg} \mathrm{~N} \mathrm{ha}^{-1}$ between 1992 and 2004 (Chiang et al. 2010).

Nutrient models for this watershed estimated that between 3\% and 39\% increases in $\mathrm{N}$ losses would occur if excess nutrients were available in combination with minimal plant growth. This situation occurred if overgrazing and summer or fall applications of poultry litter were used. The range in estimated $\mathrm{N}$ losses was influenced by weather variability (Chaubey et al. 2010). These landscape level effects highlight the importance of combining forages with comprehensive soil conservation management.

\section{Sound Management Maximizes Soil Conservation Benefits}

Soil conservation benefits from forages are generally determined by site-specific management practices. The need 
Table 12.10 Examples of plants suitable for both mineland reclamation and forage potential

\begin{tabular}{|c|c|c|c|c|c|}
\hline Common name & Type & United States region & Note & Suitable soil textures & Forage \\
\hline Alkali sacaton & $\begin{array}{l}\text { Perennial, warm-season, } \\
\text { bunchgrass }\end{array}$ & Arid, semi-arid Western & Tolerates saline soils & Light to heavy & Good source \\
\hline Great basin wildrye & $\begin{array}{l}\text { Perennial, cool-season, } \\
\text { bunchgrass }\end{array}$ & Western & $\begin{array}{l}\text { Tolerates acidic and heavy } \\
\text { metals }\end{array}$ & Loamy to sandy & $\begin{array}{l}\text { Provides winter forage, } \\
\text { avoid heavy grazing } \\
\text { during active growth }\end{array}$ \\
\hline Black grama & Warm-season, stoloniferous & Southwest & & $\begin{array}{l}\text { Dry-gravelly, sandy, } \\
\text { sandy-loam }\end{array}$ & $\begin{array}{l}\text { Sustained forage } \\
\text { production }\end{array}$ \\
\hline Coastal panicgrass & $\begin{array}{l}\text { Perennial, Warm-season, } \\
\text { bunchgrass }\end{array}$ & $\begin{array}{l}\text { Mid-Atlantic coastal plain, } \\
\text { and piedmont regions }\end{array}$ & Salt-tolerant & $\begin{array}{l}\text { Coarse to fine, including } \\
\text { coastal dunes }\end{array}$ & Fair palatable graze \\
\hline Florida paspalum & $\begin{array}{l}\text { Perennial, warm-season, } \\
\text { bunchgrass }\end{array}$ & Southeast United States & Facultative wetland plant & Coarse to moderately fine & $\begin{array}{l}\text { Palatable, forage value } \\
\text { highest for earlier growth } \\
\text { stages, not } \\
\text { recommended as grazing } \\
\text { monoculture }\end{array}$ \\
\hline Orchardgrass & $\begin{array}{l}\text { Perennial, cool-season, } \\
\text { bunchgrass }\end{array}$ & Nationwide & $\begin{array}{l}\text { Not adapted for saline or } \\
\text { high-water table soils, } \\
\text { invasive potential }\end{array}$ & Clay to gravelly loams & Cool season forage \\
\hline Sideoats grama & $\begin{array}{l}\text { Perennial, warm-season, } \\
\text { bunchgrass }\end{array}$ & Nationwide & $\begin{array}{l}\text { Moderately tolerable of } \\
\text { saline soils }\end{array}$ & Coarse to fine & $\begin{array}{l}\text { Plants need } 12 \text { months } \\
\text { development before } \\
\text { grazing }\end{array}$ \\
\hline
\end{tabular}

Source: Adapted from USDA NRCS Plant Materials Program Conservation Plant Releases (USDA NRCS 2017). 
for additional quantitative information on how soil management practices affect a range of soil types remains a long-recognized issue (Pierre 1946). For example, forages tend to increase aggregation, particularly for larger soil aggregates ( $>1$ or $>2 \mathrm{~mm}$ ). Forage effects on soil properties within grazing management systems are affected by stocking rates, soil moisture content, crop cover, and landscape position (Russell and Bisinger 2015). Soil conservation benefits may be seen at the soil surface, such as from 0 to $5-\mathrm{cm}$, and may extend down the soil profile, as occurred in alfalfa water use in saline seep areas.

Theoretically, the forage effect on soil properties depends on which forages are grown, site management (planting, harvesting, etc.), and how forages are utilized (cover crop, crop rotation, animal forage, etc). This chapter has highlighted several ways forages affect soil properties. Well-informed site-specific management can ensure forages help maintain and build a stable soil resource. For example, as noted by Pierre in 1946, there was a "relatively new forage crop combination" available in the Midwest US that included smooth bromegrass and alfalfa. This combination produced quality forage, and had "high value in soil improvement and conservation." However, Pierre noted, "whether or not (the forage crop combination) makes the contribution to soil improvement in the Corn Belt that it can, however, will probably depend largely on its management" (Pierre 1946 , p. 5). This management included incorporating the forage into a crop rotation rather than planting it permanently, separate from other crops. Seventy years later, this recommendation remains the same.

\section{References}

Andrews, S.S., Karlen, D.L., and Cambardella, C.A. (2004). The soil management assessment framework: a quantitative soil quality evaluation method. Soil Sci. Soc. Am. J. 68: 1945-1962.

Andrews, M., Edwards, G.R., Ridgway, H.J. et al. (2011). Positive plant microbial interactions in perennial ryegrass dairy pasture systems. Ann. Appl. Bio. 159: 79-92.

Angers, D.A. (1992). Changes in soil aggregation and organic carbon under corn and alfalfa. Soil Sci. Soc. Am. J. 56: 1244-1249.

Angers, D.A. and Caron, J. (1998). Plant-induced changes in soil structure: processes and feedbacks. Biogeochemistry 42: 55-72.

Bach, E.M. and Hofmockel, K.S. (2016). A time for every season: soil aggregate turnover stimulates decomposition and reduces carbon loss in grasslands managed for bioenergy. GCB Bioenergy 8: 588-599.

Bandick, A.K. and Dick, R.P. (1999). Field management effects on soil enzyme activities. Soil Biol. Biochem. 31: 1471-1479.
Bartel, C.A., Banik, C., Lenssen, A.W. et al. (2017). Establishment of perennial groundcovers for maize-based bioenergy production systems. Agron. J. 109: 822-835.

Barth, R.C. and Martin, B.K. (1984). Soil depth requirements for revegetation of surface-mined areas in Wyoming, Montana, and North Dakota. J. Environ. Qual. 13 (3): 399-404.

Basche, A.D., Kaspar, T.C., Archontoulis, S.V. et al. (2016). Soil water improvements with the long-term use of a winter rye cover crop. Agr. Water Manage 172: 40-50.

van Bavel, C.H.H. and Schaller, F.W. (1951). Soil aggregation, organic matter, and yields in a long-time experiment as affected by crop management. Soil Sci. Soc. Am. J. 15: 399-404.

Bennett, H.H. and Chapline, W.R. (1928). Soil Erosion a National Menace. USDA Circular No. 33. Washington: United States Government Printing Office.

Bowatte, S., Newton, P.C.D., Hoogendoorn, C.J. et al. (2015). Wide variation in nitrification activity in soil associated with different forage plant cultivars and genotypes. Grass Forage Sci. 71: 160-171.

Browning, G.M. (1951). Forages and soil conservation. In: Forages: The Science of Grassland Agriculture (eds. H.D. Hughes, M.E. Heath and D.S. Metcalfe), 38-53. Ames, Iowa: The Iowa State College Press.

Browning, G.M., Norton, R.A., McCall, A.G., and Bell, F.G. (1948). Investigation in Erosion Control and the Reclamation of Eroded Land at the Missouri Valley Loess Conservation Experiment Station, Clarinda, Iowa, 1931-1942. Washington, D.C.: USDA Soil Conservation Service USDA Technical Bulletin No. 959. Available online: https://naldc.nal.usda.gov/naldc/ download.xhtml?id=CAT86200951\&content=PDF.

Caron, J., Kay, B.D., and Perfect, E. (1992). Short-term decrease in soil structural stability following bromegrass establishment on a clay loam soil. Plant Soil 145: 121-130.

Carvalho, J.L.N., Raucci, G.S., Cerri, C.E.P. et al. (2010a). Impact of pasture, agriculture and crop-livestock systems in soil C stocks in Brazil. Soil Till. Res. 110: 175-186.

Carvalho, P.C.F., Anghinoni, I., Moraes, A. et al. (2010b). Managing grazing animals to achieve nutrient cycling and soil improvement in no-till integrated systems. Nutr. Cycl. Agroecosyst. 88: 259-273.

Causarano, H.J., Franzluebbers, A.J., Shaw, J.N. et al. (2008). Soil organic carbon fractions and aggregation in the Southern Piedmont and Coastal Plain. Soil Sci. Soc. Am. J. 72 (1): 221-230.

Chan, K.Y., Conyers, M.K., Li, G.D. et al. (2011). Soil carbon dynamics under different cropping and pasture management in temperature Australia: results of three long-term experiments. Soil Res. 49: 320-328. 
Chaubey, I., Chiang, L., Gitau, M.W., and Mohamed, S. (2010). Effectiveness of best management practices in improving water quality in a pasture-dominated watershed. J. Soil Water Conserv. 65 (6): 424-437.

Cherubin, M.R., Karlen, D.L., Cerri, C.E.P. et al. (2016). Soil quality indexing strategies for evaluating sugarcane expansion in Brazil. PLoS One 11 (3): e0150860. https://doi.org/10.1371/journal.pone.015086.

Chiang, L., Chaubey, I., Gitau, M.W., and Arnold, J.G. (2010). Differentiating impacts of land use changes from pasture management in a CEAP watershed using the SWAT model. Trans. ASABE 53 (5): 1569-1584.

Congreves, K.A., Hayes, A., Verhallen, E.A., and Van Eerd, L.L. (2015). Long-term impact of tillage and crop rotation on soil health at four temperate agroecosystems. Soil Tillage Res. 152: 17-28.

Cornell University (2010). Cover crops for vegetable growers. http://covercrops.cals.cornell.edu/decisiontool.php (accessed 9 October 2019).

Crotty, F.V., Fychan, R., Scullion, J. et al. (2015). Assessing the impact of agricultural forage crops on soil biodiversity and abundance. Soil Biol. Biochem. 91: 119-126.

Cuttle, S.P. (2008). Impacts of pastoral grazing on soil quality. In: Environmental Impacts of Pasture-based Farming (ed. R.W. McDowell), 33-74. Wallingford: CABI.

Detheridge, A.P., Brand, G., Fychan, R. et al. (2016). The legacy effect of cover crops on soil fungal populations in a cereal rotation. Agr. Ecosyst. Environ. 228: 49-61.

Dignam, B.E.A., O'Callaghan, M., Condron, L.M. et al. (2016). Challenges and opportunities in harnessing soil disease suppressiveness for sustainable pasture production. Soil Biol. Biochem. 95: 100-111.

Elliott, E.T. (1986). Aggregate structure and carbon, nitrogen, and phosphorus in native and cultivated soils. Soil Sci. Soc. Am. J. 50: 627-633.

FAO (2017a). Grasslands, rangelands, and forage crops. http://www.fao.org/agriculture/crops/thematicsitemap/theme/spi/grasslands-rangelands-and-foragecrops/en/ (accessed 9 October 2019).

FAO (2017b). FAOSTAT. http://www.fao.org/faostat (accessed 9 October 2019).

Fox, G.A., Sheshukov, A., Cruse, R. et al. (2016). Reservoir sedimentation and upstream sediment sources: perspectives and future research needs on streambank and gully erosion. Environ. Manage. 57: 945-955.

Franzen, D. (2013). Managing saline soils in North Dakota. North Dakota State University Extension Publication SF1087. https://www.ag.ndsu.edu/ publications/landing-pages/crops/managing-salinesoils-in-north-dakota-sf-1087 (accessed 9 October 2019).

Franzluebbers, A.J. and Stuedemann, J.A. (2009). Soil-profile organic carbon and total nitrogen during
12 years of pasture management in the Southern Piedmont USA. Agr. Ecosyst. Environ. 129: 28-36.

Grandy, A.S. and Robertson, G.P. (2007). Land-use intensity effects on soil organic carbon accumulation rates and mechanisms. Ecosystems 10: 58-73.

Haas, H.J., Evans, C.E., and Miles, E.F. (1957). Nitrogen and Carbon Changes in Great Plains Soils as Influenced by Cropping and Soil Treatments. USDA ARS Technical Bulletin 1164. Washington: U.S. Government Printing Office.

Halvorson, A.D. and Richardson, J.L. (2011). Management of dryland saline seeps. In: Agricultural Salinity Assessment and Management, 2e (eds. W.W. Wallender and K.K. Tanji), 561-589. Reston, VA: US: ASCE.

Harman, M.B., Thompson, J.A., Pena-Yewtukhiw, E.M. et al. (2011). Preferential flow in pastures on benchmark soils in West Virginia. Soil Sci. 176 (10): 509-519.

Harris, R.F., Chesters, G., and Allen, O.N. (1966). Dynamics of soil aggregation. Adv. Agron. 18: 107-169.

Haynes, R.J. (1999). Size and activity of the soil microbial biomass under grass and arable management. Bio. Fertil. Soils 30: 210-216.

Haynes, R.J. and Williams, P.H. (1993). Nutrient cycling and soil fertility in the grazed pasture ecosystem. $A d v$. Agron. 49: 119-199.

Helmers, M.J., Zhou, X., Asbjornsen, H. et al. (2012). Sediment removal by prairie filter strips in row-cropped ephemeral watersheds. J. Environ. Qual. 41: 1531-1539.

Jabro, J.D., Sainju, U., Stevens, W.B., and Evans, R.G. (2008). Carbon dioxide flux as affected by tillage and irrigation in soil converted from perennial forages to annual crops. J. Environ. Manage. 88: 1478-1484.

Jahanzad, E., Barker, A.V., Hashemi, M. et al. (2016). Nitrogen release dynamics and decomposition of buried and surface cover crop residues. Agron. J. 108: 1735-1741.

Jokela, W., Posner, J., Hedtcke, J. et al. (2011). Midwest cropping system effects on soil properties and on a soil quality index. Agron. J. 103: 1552-1562.

Karki, U. and Goodman, M. (2011). Short-term soil quality response to forage species and $\mathrm{pH}$. Grass Forage Sci. 66: 290-299.

Karlen, D.L., Stott, D.E., Cambardella, C.A. et al. (2014). Surface soil quality in five midwestern cropland conservation effects assessment project watersheds. J. Soil Water Conserv. 69 (5): 393-401.

Karlen, D.L., Goeser, N.J., Veum, K.S., and Yost, M.A. (2017). On-farm soil health evaluations: challenges and opportunities. J. Soil Water Conserv. 72 (2): 26A-31A. 
Kaspar, T.C., Radke, J.K., and Laflen, J.M. (2001). Small grain cover crops and wheel traffic effects on infiltration, runoff, and erosion. J. Soil Water Conserv. 56 (2): 160-164.

Kemper, W.D. and Koch, E.J. (1966). Aggregate Stability of Soils from Western United States and Canada. USDA ARS Technical Bulletin No. 1355. Washington: U.S. Government Printing Office.

Kumwenda, J.D.T., Radcliffe, D.E., Hargrove, W.L., and Bridges, D.C. (1993). Reseeding of crimson clover and corn grain yield in a living mulch system. Soil Sci. Soc. Am. J. 57: 517-523.

Maas, E.V. and Grattan, S.R. (1999). Crop yields as affected by salinity. In: Agricultural Drainage, Agronomy Monograph 38 (eds. R.W. Skaggs and J. van Schilfgaarde), 55-108. Madison, WI: ASA, CSSA, SSSA.

Masters, D.G., Benes, S.E., and Norman, H.C. (2007). Biosaline agriculture for forage and livestock production. Agr. Ecosyst. Environ. 119: 234-248.

McCauley, A. and Jones, C. (2005). Salinity \& sodicity management. Land Resources and Environmental Studies. http://landresources.montana.edu/swm/ documents/SW 2 updated.pdf (accessed 9 October 2019).

McCracken, R.J. (1959). Certain Properties of Selected Southeastern United States Soils and Mineralogical Procedures for Their Study. Southern Regional Bull. 61. Blacksburg: Virginia Agricultural Experiment Station, Virginia Polytechnic Institute.

McNally, S.R., Laughlin, D.C., Rutledge, S. et al. (2015). Root carbon inputs under moderately diverse sward and conventional ryegrass-clover pasture: implications for soil carbon sequestration. Plant Soil 392: 289-299.

Meek, B.D., Rechel, E.A., Carter, L.M., and DeTar, W.R. (1989). Changes in infiltration under alfalfa as influenced by time and wheel traffic. Soil Sci. Soc. Am. J. 53: 238-241.

Meek, B.D., Rechel, E.R., Carter, L.M. et al. (1992). Infiltration rate of a sandy loam soil: effects of traffic, tillage, and plant roots. Soil Sci. Soc. Am. J. 56: 908-913.

Midwest Cover Crops Council (MCCC) (2017). Midwest cover crops council - cover crop decision tool. http://mccc.msu.edu/covercroptool/covercroptool .php (accessed 9 October 2019).

Miller, D.E., Bunger, W.C., and Proebsting, E.L. Jr. (1963). Properties of soil in orchard as influenced by travel and cover crop management systems. Agron. J. 55 (2): 188-191.

Miller, M.R., Brown, P.L., Donovan, J.J. et al. (1981). Saline seep development and control in the North American Great Plains - hydrogeological aspects. Agr. Water Manage. 4: 115-141.

Moebius-Clune, B.N., Moebius-Clune, D.J., Gugino, B.K. et al. (2016). Comprehensive Assessment of Soil Health - The Cornell Framework Manual, 3e,
1. Geneva, NY: Cornell University http://www.css .cornell.edu/extension/soil-health/manual.pdf.

Moir, J.L., Edwards, G.R., and Berry, L.N. (2012). Nitrogen uptake and leaching loss of thirteen temperate grass species under high N loading. Grass Forage Sci. 68: 313-325.

Moore, E.B., Wiedenhoeft, M.H., Kaspar, T.C., and Cambardella, C.A. (2014). Rye cover crop effects on soil quality in no-till corn silage-soybean cropping systems. Soil Sci. Soc. Am. J. 78: 968-976.

Nakamoto, T. and Tsukamoto, M. (2006). Abundance and activity of soil organisms in fields of maize grown with a white clover living mulch. Agr. Ecosyst. Environ. 115: 34-42.

National Research Council (2005). Mineral Tolerance of Animals, 2e. Washington: National Academies Press.

Necpálová, M., Li, D., Lanigan, G. et al. (2013). Changes in soil organic carbon in a clay loam soil following ploughing and reseeding of permanent grassland under temperate moist climatic conditions. Grass Forage Sci. 69: 611-624.

Osterholz, W.R., Rinot, O., Liebman, M., and Castellano, M.J. (2017). Can mineralization of soil organic nitrogen meet maize nitrogen demand? Plant Soil https:// doi.org/10.1007/s11104-016-3137-1.

Page, J.B. and Willard, C.J. (1947). Cropping systems and soil properties. Soil Sci. Soc. Am. J. 11: 81-88.

Panagos, P., Borrelli, P., Meusburger, K. et al. (2015). Estimating the soil erosion cover-management factor at the European scale. Land Use Policy 48: 38-50.

Pantoja, J.L., Woli, K.P., Sawyer, J.E., and Barker, D.W. (2016). Winter rye cover crop biomass production, degradation, and nitrogen recycling. Agron. J. 108: 841-853.

Penn State (n.d.). Forage selection tool. http://www .forages.psu.edu/selection_tool/index.html (accessed 9 October 2019).

Perfect, E., Kay, B.D., van Loon, W.K.P. et al. (1990). Rates of change in soil structural stability under forages and corn. Soil Sci. Soc. Am. J. 54: 179-186.

Pierre, W.H. (1946). A look forward in the management of corn belt soils. Soil Sci. Soc. Am. J. 10: 3-8.

Pilon, C., Moore, P.A. Jr., Pote, D.H. et al. (2017). Long-term effects of grazing management and buffer strips on soil erosion from pastures. J. Environ. Qual. 46: 364-372.

Pilon-Smits, E. (2005). Phytoremediation. Annu. Rev. Plant Biol. 56: 15-39.

Qi, Z., Helmers, M.J., and Kaleita, A.L. (2011). Soil water dynamics under various agricultural land covers on a subsurface drained field in north-central Iowa, USA. Agr. Water Manage. 98: 665-674.

Rasiah, V. and Kay, B.D. (1994). Characterizing changes in aggregate stability subsequent to introduction of forages. Soil Sci. Soc. Am. J. 58: 935-942. 
Reicosky, D.C., Kemper, W.D., Langdale, G.W. et al. (1995). Soil organic matter changes resulting from tillage and biomass production. J. Soil Water Conserv. 50 (3): 253-261.

Ross, S.M., Izaurralde, R.C., Janzen, H.H. et al. (2008). The nitrogen balance of three long-term agroecosystems on a boreal soil in western Canada. Agr. Ecosyst. Environ. 127: 241-250.

Rücknagel, J., Götze, P., Koblenz, B. et al. (2016). Impact on soil physical properties of using large-grain legumes for catch crop cultivation under different tillage conditions. Eur. J. Agron. 77: 28-37.

Russell, J.R. and Bisinger, J.J. (2015). Improving soil health and productivity on grasslands using managed grazing of livestock. J. Anim. Sci. 93: 2626-2640.

Salton, J.C., Mercante, F.M., Tomazi, M. et al. (2014). Integrated crop-livestock in tropical Brazil: toward a sustainable production system. Agr. Ecosyst. Environ. 190: 70-79.

SARE (2017a). Cover crop surveys. http://www.sare.org/ Learning-Center/Topic-Rooms/Cover-Crops/CoverCrop-Surveys (accessed 9 October 2019).

SARE (2017b). Cover crops: selection and management. http://www.sare.org/Learning-Center/TopicRooms/Cover-Crops/Cover-Crops-Selection-andManagement (accessed 9 October 2019).

Schipper, L.A., Parfitt, R.L., Fraser, S. et al. (2014). Soil order and grazing management effects on changes in soil $\mathrm{C}$ and $\mathrm{N}$ in New Zealand pastures. Agr. Ecosyst. Environ. 184: 67-75.

Lisa Schulte-Moore, Lisa, de Kok-Mercado, Omar, and Love, Fred. (2020). ISU researchers pave the way to make prairie strips eligible option for federal conservation program. https://www.news.iastate.edu/news/ 2020/01/09/stripscrp (accessed 25 February 2020).

Silveira, M.L., Liu, K., Sollenberger, L.E. et al. (2013). Short-term effects of grazing intensity and nitrogen fertilization on soil organic carbon pools under perennial grass pastures in the southeastern USA. Soil Biol. Biochem. 58: 42-49.

Steppuhn, H., van Genuchten, M.T., and Grieve, C.M. (2005). Root-zone salinity: II. Indices for tolerance in agricultural crops. Crop Sci. 45: 221-232.

Steppuhn, H., Acharya, S.N., Iwaasa, A.D. et al. (2012). Inherent responses to root-zone salinity in nine alfalfa populations. Can. J. Plant Sci. 92: 235-248.

Stone, J.A. and Buttery, B.R. (1989). Nine forages and the aggregation of a clay loam soil. Can. J. Soil Sci. 69: 165-169.

Tomer, M.D. and Locke, M.A. (2011). The challenge of documenting water quality benefits of conservation practices: a review of USDA-ARS's conservation effects assessment project watershed studies. Water Sci. Technol. 64 (1): 300-310.
Turner, B.L. and Haygarth, P.M. (2005). Phosphatase activity in temperate pasture soils: potential regulation of labile organic phosphorus turnover by phosphodiesterase activity. Sci. Total Environ. 344: 27-36.

USDA (2015). Summary Report: 2012 National Resources Inventory. Washington, DC and Ames, Iowa: Natural Resources Conservation Service and Center for Survey Statistics and Methodology, Iowa State University https://www.nrcs.usda.gov/Internet/FSE_ DOCUMENTS/nrcseprd396218.pdf.

USDA NRCS (2014). Bare ground, inter-canopy gaps, and soil aggregate stability. National resources inventory rangeland resource assessment. https://www.nrcs .usda.gov/wps/portal/nrcs/detail/national/technical/ nra/nri/results/?cid=stelprdb1254158 (accessed 9 October 2019).

USDA NRCS (2016). Pacific Northwest cover crop selection tool. https://www.nrcs.usda.gov/wps/portal/ $\mathrm{nrcs} /$ detail/plantmaterials/technical/toolsdata/plant/? cid=nrcseprd894840 (accessed 9 October 2019).

USDA NRCS (2017). Conservation plant releases. https://www.nrcs.usda.gov/wps/portal/nrcs/releases/ plantmaterials/technical/cp/release/ (accessed 9 October 2019).

Veum, K.S., Goyne, K.W., Kremer, R.J. et al. (2014). Biological indicators of soil quality and soil organic matter characteristics in an agricultural management continuum. Biogeochemistry 117: 81-99.

Wang, X., VandenBygaart, A.J., and McConkey, B.C. (2014). Land management history of Canadian grasslands and the impact on soil carbon storage. Rangeland Ecol. Manage. 67: 333-343.

White, C.M. and Weil, R.R. (2010). Forage radish and cereal rye cover crop effects on mycorrhizal fungus colonization of maize roots. Plant Soil 328: 507-521.

White, C.M. and Weil, R.R. (2011). Forage radish cover crops increase soil test phosphorus surrounding radish taproot holes. Soil Sci. Soc. Am. J. 75: 121-130.

Wick, A.F., Merrill, S.D., Toy, T.J., and Liebig, M.A. (2011). Effect of soil depth and topographic position on plant productivity and community development on 28-year-old reclaimed mine lands. J. Soil Water Conserv. 66 (3): 201-211.

Wiebe, B.H., Eilers, R.G., Eilers, W.D., and Brierley, J.A. (2007). Application of a risk indicator for assessing trends in dryland salinization risk on the Canadian Prairies. Can. J. Soil Sci. 87: 212-224.

Wilson, H.A., Gish, R., and Browning, G.M. (1948). Cropping systems and season as factors affecting aggregate stability. Soil Sci. Soc. Am. J. 12: 36-38.

Ziyomo, C., Albrecht, K.A., Baker, J.M., and Bernardo, R. (2013). Corn performance under managed drought stress and in a kura clover living mulch intercropping system. Agron. J. 105 (3): 579-586. 
Zobeck, T.M., Crownover, J., Dollar, M. et al. (2007). Investigation of soil conditioning index values for southern high plains agroecosystems. J. Soil Water Conserv. 62 (6): 433-442.
Zobeck, T.M., Halvorson, A.D., Wienhold, B. et al. (2008). Comparison of two soil quality indexes to evaluate cropping systems in northern Colorado. J. Soil Water Conserv. 63 (5): 329-338. 